political thought and philosophy, Shklar was named a MacArthur Fellow in 1984.

In addition to Shklar, the 1988 Nominating Committee proposed the following slate for Association officers and Council members:

Vice-Presidents (1988-89): Murray Edelman, University of Wisconsin; Robert Jervis. Columbia University; Martin Shapiro, University of California, Berkeley.

Secretory (1988-89): Daniel J. Elazar, Temple University.

Council (1988-90): Christopher Achen, University of Chicago; Kathleen Frankovic, CBS News, New York City; Peter A. Gourevitch, University of California, San Diego; Ted R. Gurr, University of Colorado; Ronald Kahn, Oberlin College; Barbara J. Nelson, University of Minnesota; Adolph Reed, Jr., Yale University; Donald Searing, University of North Carolina.

Under APSA's constitution the preceding nominations are subject to the vote of those members of the Association attending the Annual Business Meeting. If there is a contest for any elected office, an election will be conducted by mail ballot. Ballots will be distributed within 30 days of the Annual Business Meeting by the executive director. They must be returned within 30 days following distribution.

The 1988 Annual Business Meeting rules are printed in the Gazette section of this issue of PS. The rules require that any nominations in addition to those made by the Nominating Committee must be received in writing at the Association's Washington office prior to Monday, August 29, 1988, or thereafter at the Association's annual meeting office in the hotel headquarters. All such nominations and certifications must be received at least 24 hours before the session of the Annual Business Meeting in order to include those names on the original nominating document. Specific procedures for offering nominations are included in the Annual Business Meeting rules.

Members of the 1988 Nominating Committee are: Arlene Saxonhouse (chair), University of Michigan; Jennifer Hochschild, Princeton University; Herbert Jacob, Northwestern University; Samuel Popkin, University of California, San Diego; Glenn
Snyder, University of North Carolina; and Myron Weiner, Massachusetts Institute of Technology.

Continuing Council members from September 1988-September 1989 are: President: Lucian W. Pye, Massachusetts Institute of Technology. Treasurer: Nancy $H$. Zingale, College of St. Thomas. Council (1987-88): William I. Bacchus, Department of State; Donald Kinder, University of Michigan; Jane Mansbridge, Northwestern University; Dianne Pinderhughes, University of Illinois at Urbana-Champaign; Margaret E. Scranton, University of Arkansas, Little Rock; Mary Shanley, Vassar College; Richard A. Watson, University of Missouri; and Aristide Zolberg, New School for Social Research.

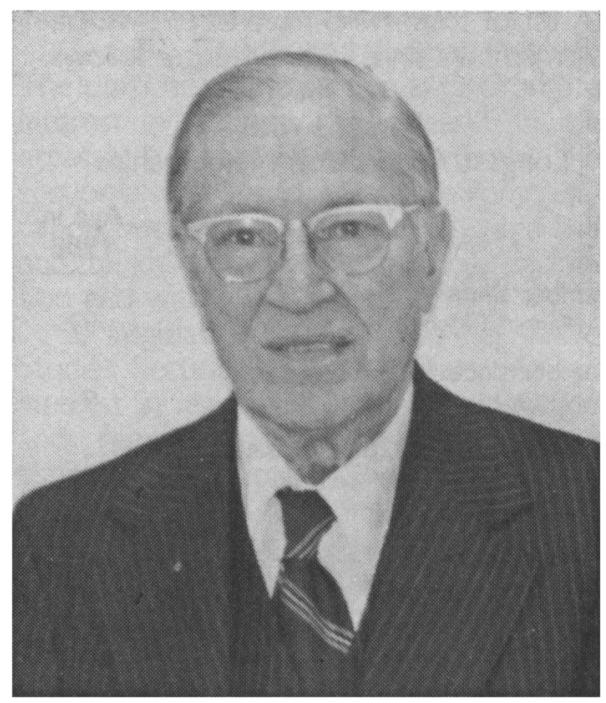

HAROLD GOSNELL

\section{Gosnell Is Longest Continuous APSA Member}

Jean Walen

American Political Science Association

A check of Association membership records shows that the longest continuous 
membership (67 years) belongs to Harold Gosnell who joined the Association in 1921. Over 100 Association members have been members of the Association for nearly 50 years or longer; 12 have been members for 60 years or more.

Gosnell lives in the Washington area, still attends annual meetings when they are held in Washington, is active in the National Capital Area Political Science Association, and keeps busy working on his autobiography and a "long reading list." He received his Ph.D. from the University of Chicago in 1922. He taught at Howard and American Universities in Washington, D.C. and worked for various government agencies in Washington. He served on the Council of the Association 1941-43. He was the recipient of the Association's Charles E. Merriam Award in 1981.

A list of those who have been Association members since 1940 or longer follows:

\section{Persons with Longest Association Memberships}

Member since 1921-67 years Harold Gosnell

\section{Age in}

1988

Member since 1924-64 years

N. D. Houghton

\section{2}

Members since 1926-62 years Francis Aumann Marshall Dimock

Members since 1927-61 years Clarence Berdahl

*R. Taylor Cole

J. Roland Pennock

Llewellyn Pfankuchen

Joseph Pois

Harry Voltmer

Members since 1928-60 years

H. S. Foster

Dale Pointius

Member since 1929-59 years

Benjamin Lippincott

Members since 1930-58 years Winston Crouch George A. Graham Albert Lepawsky Harvey Mansfield Sr.

*Emmette Redford Carroll Shaw
Members since 1931-57 years

David Fellman

Charles Hagan

Members since 1932-56 years

Arthur Bromage

Benjamin Rowe

O. G. Stahl

Belle Zeller

Members since 1933-55 years

John Ferguson

Robert McCulloch

Dean E. McHenry

${ }^{*} \mathrm{C}$. Herman Pritchett

Henry Reining

Victoria Schuck

Estal Sparlin

Karl Stromsen

Members since 1934-54 years

Willard Barber

William $O$. Farber

James Fesler

G. Lowell Field

Robert J. Harris

Members since 1935-53 years

W. T. R. Fox

M. R. Goldschmidt John D. Millett

Members since 1936-52 years

Quirino Austria

Henrietta Fernitz

Walter J. Moberg

Lewis Sims

Robert A. Walker

Members since 1937-51 years

Weldon Cooper

C. N. Fortenberry

Thomas Geary

John Hallowell

*Avery Leiserson

David Levitan

Edward G. Lewis

Boyd A. Martin

William J. Ronan

Martin D. Scwartz

*David B. Truman

Vernon Van Dyke

C. Dwight Waldo

76

75

75

73

76

77

76

71

75

76

75

Members since 1938-50 years

Gwendolen Carter

Arthur Funston

F. A. Hermens

Frank Klingberg

G. S. Pancoast

Elmer Plischke 


$\begin{array}{ll}\text { Members since 1939-49 years } & \\ \text { *Gabriel Almond } & 77 \\ \text { Totten Anderson } & 79 \\ \text { Helen Arnold } & 86 \\ \text { *Samuel Beer } & 77 \\ \text { Oliver Benson } & 77 \\ \text { G. C. Benson } & 80 \\ \text { Alex Dragnich } & 76 \\ \text { J. W. Drury } & 69 \\ \text { John H. Fried } & 83 \\ \text { Erich Hula } & 88 \\ \text { Marian Irish } & 79 \\ \text { Majid Khadduri } & 79 \\ \text { Ruth Lawson } & 77 \\ \text { W. S. Payne } & 71 \\ \text { Robert Rawson } & 75 \\ \text { Landon G. Rockwell } & 74 \\ \text { Carl Schneider } & 71 \\ \text { Donald Strong } & 76 \\ \text { Albert Sturm } & 77 \\ \text { Carl W. Tiller } & 73 \\ \text { William Torpey } & 75 \\ \text { Richard A. Ware } & 69 \\ \text { Members since I940-48 years } & \\ \text { Vincent J. Browne } & 71 \\ \text { John A. Davis } & 76 \\ \text { Howard E. Dean } & 72 \\ \text { Ferrel Heady } & 72 \\ \text { J. D. Heinlein } & 76 \\ \text { R. M. Kempner } & 89 \\ \text { Evron M. Kirkpatrick } & 77 \\ \text { Edward B. Kovar } & 71 \\ \text { John Lederle } & 77 \\ \text { Kendall Lingle } & 78 \\ \text { George T. Little } & 70 \\ \text { John F. Miller } & 80 \\ \text { Gerhart Niemeyer } & 70 \\ \text { Grady H. Nunn } & 72 \\ \text { Howard Penniman } & 72 \\ \text { Richard C. Snyder } & \\ & \end{array}$

"Former APSA presidents

\section{Organized Sections Welcome Members}

\author{
Kay Sterling \\ American Political Science Association
}

Following are brief descriptions of the foci or purposes of each of APSA's Organized
Sections. In most cases, the language used is taken directly from the original petition submitted to the Council for recognition of status as an Organized Section.

Section officers are elected during the sections' business meetings at APSA's Annual Meeting, and are listed, each year, in the fall issue of PS: Political Science \& Politics. (The most recent listing is the fall 1987 issue, p. 1025.) Many sections publish newsletters for their members; some offer awards for scholarly achievement. All are allotted panels during the Annual Meeting. For information about activities of any section, please call or write the appropriate person as indicated in the fall listing.

1. Federalism and Intergovernmental Relations: The purpose of the section is to plan, develop and implement professional activities for Association members with interests in subjects of federalism and intergovernmental relations.

2. Law, Courts and Judicial Process: The purpose of the section is to promote interest in teaching and research in the areas of law and the judicial process. The section also seeks to encourage communication between persons interested in law and the judicial process within the Association and with related disciplines.

3. Legislative Studies: The Legislative Studies Section invites members with an interest in legislative processes, behavior and representation. The section may establish special panels, workshops, symposia, or social gatherings at the APSA Annual Meeting or at such other times as may be appropriate. Members receive a newsletter. The section is closely associated with the Legislative Studies Quarterly and encourages its members to subscribe.

4. Policy Studies: The purposes of the section are to help promote the application of political science to important policy problems; aid in developing panels, workshops and roundtables for the APSA Annual Meeting and related programs for the regional political science association conventions; provide a general meeting at the APSA Annual Meeting for the discussion of issues relevant to the policy studies field; and provide ways of networking political scientists and others who are interested in policy studies, but are not necessarily members of the Policy Studies Section. 